\title{
THIS IS TOM = /ZYZYS'TOM/ PRONUNCIATION IN BEGINNERS' EFL TEXTBOOKS THEN AND NOW
}

\author{
WLODZIMIERZ SOBKOWIAK \\ IFA UAM
}

\begin{abstract}
The textbook appears to be one of the most fundamental elements of all formal-setting foreign language teaching and learning. Textbooks function in a foreign language classroom in many capacities (Cunningsworth 1995), one of which is the provision of text, used as a model for language practice, including practice of pronunciation. The changing methodological trends in EFL pedagogy over the decades affect EFL textbook pronunciation treatment in a variety of ways. In this paper a simple feasibility study is presented whereby a few beginners' textbooks are compared with respect to their handling of pronunciation in the first unit of the course. Four textbooks come from about $1 / 2$ century ago, and three are sampled from among those currently available. On the descriptive level, some analysis is offered of the phonetic (and especially phonolapsological) characteristics of the sampled texts, as they changed through time. On the level of application, it is claimed that, while the lexico-grammatical and pedagogical limitations on the content of the first lessons/units in EFL textbooks leave authors little space for phonetic control, a modicum of such control $i s$ feasible if attention is paid to such variables as pronunciation difficulty and L1 transfer. The Phonetic Difficulty Index (PDI), which is briefly introduced in the paper, can be used to measure and control some of these variables and give the textbook authors and users a useful teaching/learning instrument.
\end{abstract}

\section{Introduction}

This is a feasibility study for a much larger potential research project into the treatment of pronunciation in beginners' EFL textbooks. Part of that project would be a diachronic analysis of such textbooks over approximately half a century, to see how pronunciation is introduced to beginning learners, both explicitly and implicitly, in the text, as well as in the multimedia and online materials accompanying the recent generations of EFL textbooks. The focus is not on the specifically phonetic resources, i.e. those whose stated aim it is to teach pronunciation (see Wrembel 2004 for this perspective), but on the standard materials targeting the general population of learners, with no ESP or other bias.

The desirability of a study like this is dramatically underscored by: (i) the relative paucity of research on the handling of pronunciation in EFL textbooks on the one hand, and (ii) the fundamental importance of the textbook as the primary teaching/learning resource in most EFL classrooms around the globe. 
Considering the above factors, as well as the enormity of the EFL resource market, both synchronically and diachronically, a thorough analysis of EFL textbook phonetics would be a project of impractically grandiose proportions. In this study I can only take a closer look at some aspects of the whole issue. Consequently, I decided to concentrate on the following:

- the changing methodological trends in FL pedagogy over the last five decades affect EFL textbook pronunciation treatment in a variety of ways,

- the lexico-grammatical and pedagogical limitations on the content of EFL textbooks leave authors little space for phonetic control, but...

- $\quad$ such control of textual material is feasible if attention is paid to such variables as pronunciation difficulty and L1 transfer,

- the Phonetic Difficulty Index (PDI) can be used to help measure and control some of these variables and give the textbook authors and users a useful teaching/learning instrument.

Within the limits of this short paper, I will, try to throw some light on the above issues by taking a comparative look at the treatment of pronunciation in two small samples from EFL textbooks separated by several decades of time. The first sample comes from my own first-time EFL experience, which locates it towards the end of the 1960's. This sample includes such textbooks as: Nauka angielskiego, English for everyone, Present day English for foreign students and First things first (see References). I then compare those old textbooks with a random sample of these which can currently be found on bookshop shelves: Angielski dla samouków, Angielski nie gryzie! and Korepetycje domowe . In both cases I only look at the contents of the respective "lesson/unit one" in each of these books, with particular attention paid to how pronunciation is presented and taught.

This methodology allows no pretense of being even close to traditionally conceived scientific-empirical rigour, of course. On the one hand, for example, the old sample would probably constitute about half of all EFL textbooks of use in Poland at that time, Poland being behind the iron curtain, and EFL being discouraged, as opposed to Russian. The market of EFL resources in contemporary Poland is booming, on the other hand, and the socio-political situation is entirely different. From this point of view, then, the two samples are hardly at all comparable. I believe, however, that they can still do their service of yielding interesting preliminary and tentative insights into the issues here treated. In the study proper of EFL textbook phonetics the selected empirical textbook database would obviously need to be substantiated in a more rigorous manner.

\section{The importance of the textbook in EFL}

That the textbook is of fundamental importance in (formal) EFL teaching and learning, and that it is in the very centre of almost all EFL classrooms around the world, is hardly a controversial claim. Indeed, many teachers and educators, as well as researchers and analysts, have noticed that the status of the textbook may well be too elevated, compared

\footnotetext{
${ }^{1}$ This sample was actually taken at random from among beginning EFL textbooks available on Empik shelves in November 2011.
} 
to other available resources. This could be because the textbook plays a number of roles at the same time. In his monograph entirely devoted to choosing the coursebook for an EFL course, Cunningsworth lists the following roles:

- $\quad$ "a resource for presentation material (spoken and written)

- a source of activities for learner practice and communicative interaction

- a reference source for learners on grammar, vocabulary, pronunciation, etc

- $\quad$ a syllabus (...)

- $\quad$ a resource for self-directed learning or self-access work

- a support for less experienced teachers (...)" (Cunningsworth op cit:7)

All of these functions can, and normally do, refer to pronunciation work, including the last one listed. However, as happens to be the case, the 'support' a teacher could count on to obtain from a coursebook with respect to his/her work on pronunciation would in most cases be negative. That is to say, few general textbooks offer teachers much by way of methodological help with phonetics. Indeed, as noticed many times in relevant research, explicit and systematic treatment of pronunciation is by and large absent from most EFL coursebooks currently available (Szpyra-Kozłowska et al. 2003, SzymańskaCzaplak 2006). Thus, the teacher is 'supported' by the textbook in his/her belief that pronunciation is best left alone: "Teaching English pronunciation is an area of language teaching that many English teachers avoid" (http://www.teachingenglishgames.com/Articles/Teaching_Pronunciation.htm).

Another authority on FLT, wrote in 1981: "The importance of the textbook cannot be overestimated. It will inevitably determine the major part of the classroom teaching and the students' out-of-class learning" (Rivers 1981:475). A generation later, and in a completely different stage of the development of FLT methodology, we can find surprisingly similar observations: "The heavy reliance on a coursebook in a foreign language classroom is a crucial issue. The fact that the teachers and learners use the coursebook and its supporting materials as their basic aid proves the importance of selecting and evaluating an appropriate coursebook" (İnal 2006:22). İnal's quote immediately brings to mind two important issues. First: the work of "selecting and evaluating" does not stop at the level of the textbook as a whole; once that is selected, the teacher must often select and evaluate the contents of the textbook at hand on various levels and from the point of view of various functionalities. For example, "is the treatment of football vocabulary useful in Unit Six of my textbook, or should I try to find something better?" Second, and in direct relevance to pronunciation: it would be easy enough to select and evaluate material on the basis of how pronunciation is explicitly treated in the given unit/lesson of the course. But how can a teacher evaluate the implicit handling of pronunciation in the textbook? For example, what is the phonetic profile of the text contained in the unit? Which words might be particularly troublesome to learners? Is the phonetic difficulty progression through the coursebook in parallel with the other gradients, such as those of vocabulary or grammar? Textbooks or methodology guides bundled with them would not provide this kind of information for a number of reasons: the overall neglect of EFL pronunciation in most syllabuses, curricula and courses (cf., for example, Baran-Łucarz 2006), the paucity of relevant research guiding the materials developers, or the concomitant lack of software support for phonetic analysis of coursebook text. Later in this contribution Phonetic Difficulty Index (PDI) is used to demonstrate that some phonetic control over text is indeed feasible. 


\section{EFL textbooks then and now}

Let us now have a look at some examples of the treatment of pronunciation in coursebook texts for beginners as it was half a century ago, and as it is now. In order to do this, I will illustrate my discussion with some facsimiles of authentic textbook pages below.

Fifty (and more) years ago coursebook authors did not shy away from explicitly providing phonetic transcription from lesson one. In Figure 1 a snapshot of the very first lines of unit one is shown of a textbook by MacCallum and Thomas Watson, published in Poland in 1946.

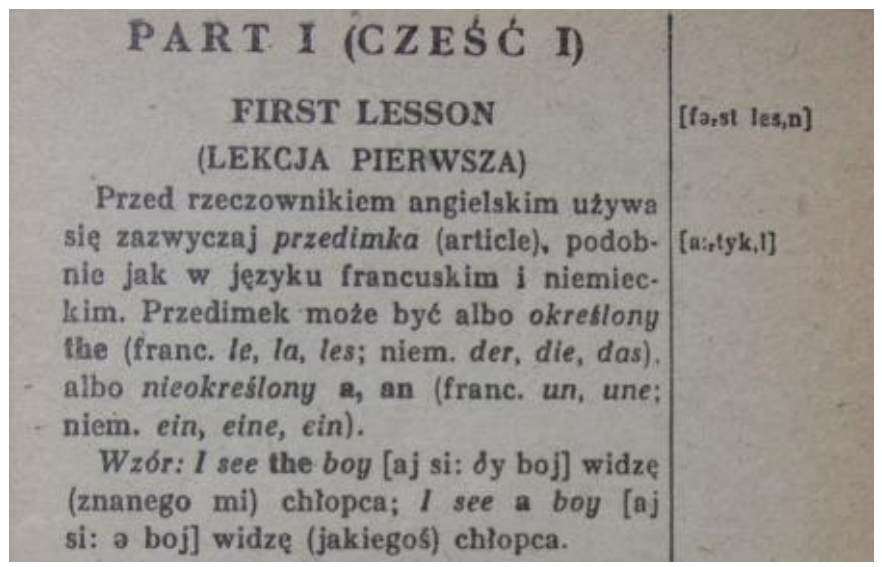

Figure 1. MacCallum and Watson, 1946

This coursebook was originally published before WW II in London, and shows clear signs of the grammar-translation method, e.g. the grammatical explanation of articles right at the very beginning of the text. On the other hand, however, the simplified phonetic transcription (see Sobkowiak 1997 for an in-depth treatment of L1-sensitive simplification of phonetic transcription) shows the influence of the new, post-war paradigm: that of audiolingualism. The learner is expected to try to speak from the very beginning. Nowadays native-speaker recording would be used instead of transcription, of course, but the principle is the same. The textbook continues with lesson one by providing a text for practice; a part of it is reproduced in Figure 2.

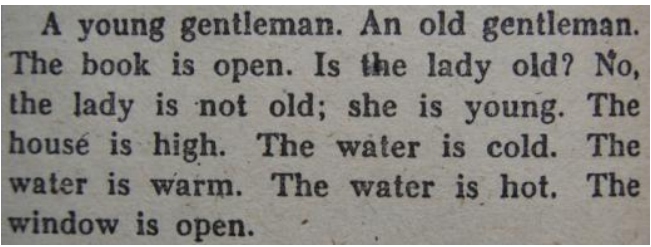

Figure 2. MacCallum and Watson, 1946 
It is samples of such introductory texts from several textbooks which will be used later in this paper to make up a mini-corpus for the application of the PDI metric. At this point let us only notice a few interesting points without going deeper into the text's phonetic structure. First, back in 1946 the EFL profession had not yet heard of the communicative method, which shows in the quality of the text: the sentences are there entirely as language specimens, rather than to really communicate anything. On the phonetic front notice the high incidence of the definite article, one of the words hardest to pronounce for a Polish EFL learner. Notice that in some cases the article could actually be avoided in this text: "water is cold" is perfectly grammatical, and pragmatically speaking even better than the original sentence (which water is cold, anyway?).

My own early learning of English was almost entirely based on the course of Frank Candlin, published in 1963. It was reprinted many times in Poland; my own 1969 Polish edition is the fourth. Figure 3 shows the very beginning of lesson one and the dialogue appearing later in the lesson.

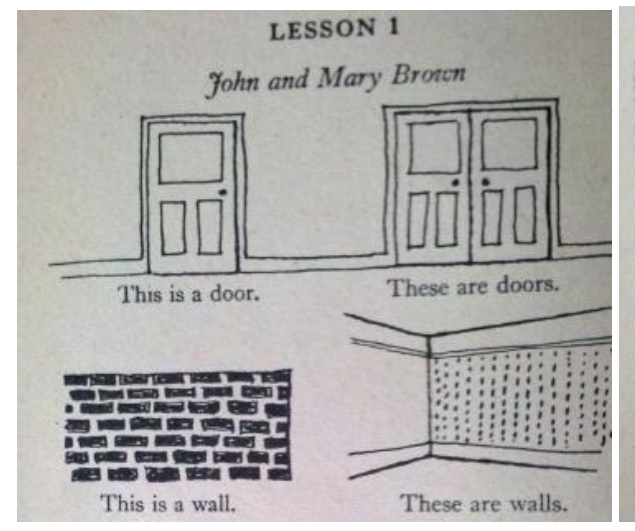

Figure 3. Frank Candlin, 1963

Like in MacCallum and Watson before, notice the heavy reliance on some of the phonetically hardest function words in English: this, these, that, those. The didactic intent of this move is clear, of course, but it is equally evident that no phonetic reflection went into the preparation of these introductory texts. The dialogue remains completely wooden, with a pragmatically most infelicitous turn at the very end, doubtless meant to illustrate a grammatical point, but misfiring badly.

It took a few more years for the communicative method to finally hit the mainstream coursebooks. In Poland it was ushered in by the immensely popular course of L.G.Alexander, published for this market in 1973. The opening dialogue in that course happened at a railway station and went like this: "Excúse me! / Yés? / Ís thís yóur hándbag? / Párdon? / Ís thís yóur hándbag? / Yés, it ís / Thánk you véry múch". Notice that: (i) word stress is indicated explicitly (and sometimes somewhat superfluously), (ii) sandhi clusters like those in the middle of "is this" are practically unpronounceable well into intermediate stages of EFL proficiency, even if the phrase is pragmatically very natural and common. While there is a lot of emphasis on spoken practice in Alexander's course, there is little explicit treatment of pronunciation, which word seemed little short 
of a four letter word to many communicatively minded methodologists. Alexander's course may well mark this turning point between audio-lingualism and communicativeness in EFL.

Finally, during my grammar school years (1970-1974) I used the then standard school textbook, Smólska and Rusiecki's English for everyone, 1965 edition. It was unique among the books discussed so far in that it treated pronunciation seriously. In Figure 4 the beginning of unit one is shown, with (Polish-simplified) phonetic transcription used throughout.

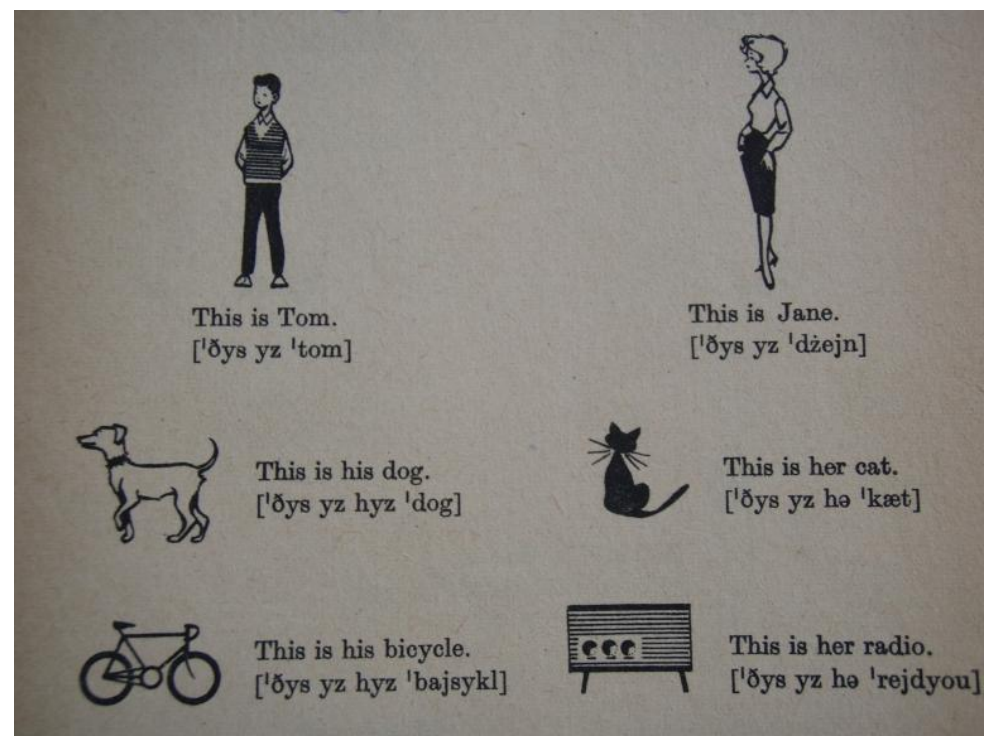

Figure 4. Smólska and Rusiecki, 1965

The customary "this is..." appears here as well, providing a lot of space for error, for example for final devoicing and/or sandhi regressive voice assimilation (typical of Polglish accents in western Poland), as shown in the title of this paper: /zyzys'tom/. In unit one of the course, i.e. one written for complete beginners, we can also find some rather sophisticated discussion of the /æ/ vowel and final devoicing, using phonetic terminology (in Polish), such as: mouth open, lower jaw, front of the tongue, incisors, tensing, devoicing.

If we now fast-forward half a century, we will find ourselves in a completely different textbook environment. Not only is there an almost uncountable variety of coursebooks and accompanying multimedia materials with online support, but the EFL teaching/learning paradigms have changed dramatically. In effect, we would be hard pressed to find any explicit treatment of pronunciation in contemporary textbooks at all. This includes phonetic transcription, too, which is maybe regarded as useless in view of the easy availability of spoken resources in the form of recordings and video files. In none of the three textbooks sampled here is there phonetic transcription in the first unit of the course. 
As a representative illustrative example let me use Birkenmajer and Mańko, published in 2004. Figure 5 holds the beginning of the first unit.

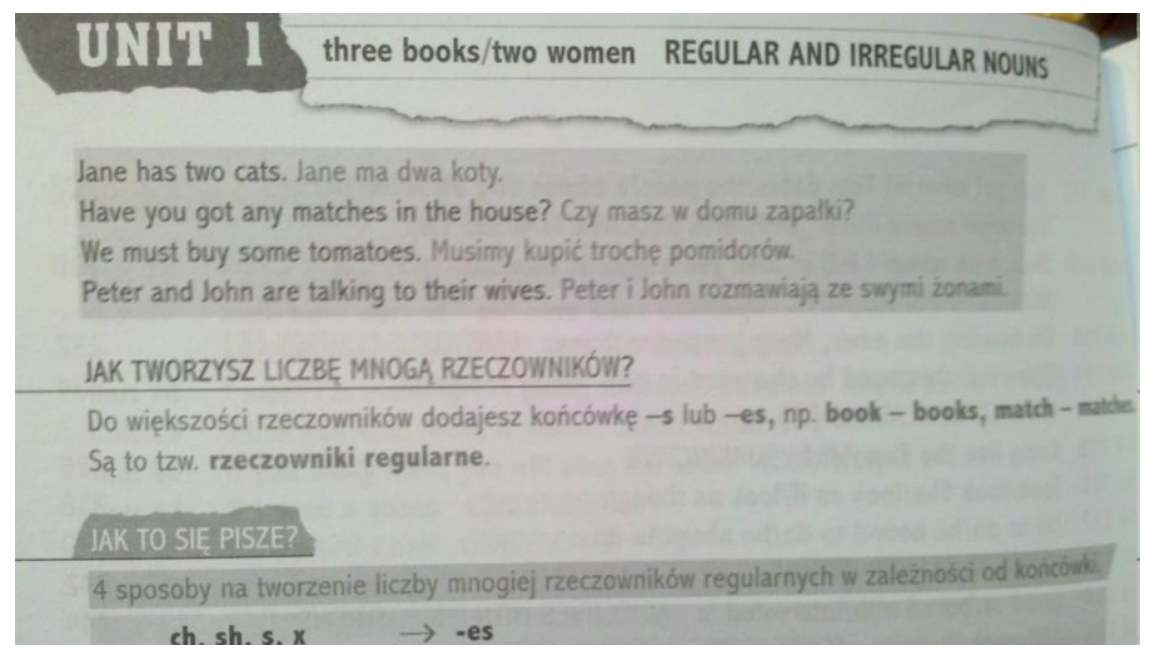

Figure 5. Birkenmajer and Mańko, 2004

The notorious "this is..." is gone. The pragmatic quality of the sentences is certainly higher than it used to be $1 / 2$ century earlier (with the notable exception of Alexander's). Birkenmajer and Mańko are not afraid to attach Polish translations to the target English sentences. Finally, from the point of view of phonetics, it is striking that there is no advice whatsoever about the pronunciation of the two morphophonemic variants of the plural morpheme.

\section{PDI analysis of the textbook sample}

While the above overview of the EFL textbooks affords some superficial appreciation of a number of phonetic issues, it would be hard to draw some more far-reaching conclusions concerning the profiling of pronunciation on the basis of a scan of introductory pages. This is why I decided, as mentioned above, to compile a mini-corpus of text, collecting all object-text taken from the seven textbooks under consideration here: four 'then' and three 'now' (see References for details). Object-text is here defined as that which is the teaching target, rather than meta-text used for unit organization, providing linguistic advice, introducing exercises, etc. Thus, the records collected in the sample would include the sentences of expository text as well as utterances in dialogues.

There are altogether 77 records in the database, each one tagged with the textbook identifier, phonetically transcribed and PDI-processed. The database can be conceptualized and visualized in a number of ways. Figure 6 shows its view in a simple lister overlay application running under Windows. 


\begin{tabular}{|c|c|c|c|c|c|c|c|c|c|}
\hline BOo & SENTENCE & |TRANS & DIFFS & DIF & WORDS & CALY & J & Z & \\
\hline cal & A young gentleman & @ MN Jentm@n & JhEHJPT3 & 2,7 & 3 & 3 & 8 & 2 & 0 \\
\hline cal & An old gentleman & @n 5ld'Jentlm@n & JYZJPT3 & 2,3 & 3 & 3 & 7 & 2 & 1 \\
\hline cal & The book is open & D@buklz'5p@n & $J L \times Z J$ & 1 & 4 & 4 & 4 & 2 & 1 \\
\hline cal & Is the lady old & $|z D @ 14 d| 5 \mid d$ & $Z J{ }^{*} Y Z$ & 1,2 & 4 & 4 & 5 & 1 & 2 \\
\hline cal & No the lady is not old she is young & n5D@ 14d lz nOt 5ld Silz ivN & "JL"ZOYZSZhEH & 1,2 & 9 & 9 & 11 & 1 & 3 \\
\hline cal & The house is high & $D @ h 2 s \mid z h 1$ & $J\lfloor h U Z$ izU & 2 & 4 & 4 & 8 & 1 & 1 \\
\hline cal & The water is cold & $D @$ 'w0t@R I $\mathrm{k} 5 \mathrm{ld}$ & JLAJJOZIYZ & 2,2 & 4 & 4 & 9 & 2 & 2 \\
\hline cal & The water is warm & D@ 'w0t@R lz w0m & JLAJ0ZO & 1,8 & 4 & 4 & 7 & 2 & 1 \\
\hline cal & The water is hot & D@ 'w0t@R I hot & JLAJOZUO & 2 & 4 & 4 & 8 & 2 & 1 \\
\hline cal & The window is open & $D @$ wind5/z 5p@n & ]JLIZJ & 1,2 & 4 & 4 & 5 & 2 & 1 \\
\hline smo & This is Tom & $\mathrm{D}|\mathrm{s}| \mathrm{z} \mathrm{tOm}$ & LZ107 & 1.7 & 3 & 3 & 5 & 0 & 1 \\
\hline smo & This is Jane & $D|s| z J 4 n$ & LZT7 & 1,3 & 3 & 3 & 4 & 0 & 1 \\
\hline smo & This is his dog & Dls $z \mathrm{hl} z \mathrm{~d} 0 \mathrm{~g}$ & LZUZZO & 1,5 & 4 & 4 & 6 & 0 & 3 \\
\hline smo & This is her cat & DIs Izh@k\&t & LZJUOI & 1,5 & 4 & 4 & 6 & 1 & 1 \\
\hline smo & This is his bicycle & Dls |z hlz'blskl & LZUZW & 1,2 & 4 & 4 & 5 & 0 & 2 \\
\hline
\end{tabular}

Figure 6. A sample of the textbook corpus/database

The highlighted record, The window is open, comes from MacCallum and Watson 1946 ('cal'). The fourth column contains the PDI difficulty codes, the DIF column shows the mean word-weighted PDI value of this record, the WORDS column holds the number of words (four), and the CALY column sums up the global PDI value of the record (nonword-weighted; five in this case). Some phonetic difficulties identified by the PDI algorithm are listed in their separate fields: thus, for example, $\mathrm{J}$ stands for schwa, and Z stands for a word-final voiced obstruent (prone to erroneous devoicing in Polglish). There are two occurrences of the former and one of the latter in The window is open.

The PDI metric and algorithm has been introduced, described and analyzed in-depth in a number of publications by Sobkowiak and Sobkowiak and Ferlacka (see References). The most concise definition is this: "PDI is a global numerical measure of the phonetic difficulty of the given English lexical item for Polish learners. The measure combines (a) the most salient grapho-phonemic difficulties such learners are known to have reading English, i.e. mostly spelling pronunciation, (b) some commonest phonemic L1-interference problems known from the literature and my own teaching experience, finally (c) some of the notorious developmental L2-interference pronunciation errors observed in all learners of English regardless of their L1 background" (Sobkowiak 1999:214). In its current implementation PDI contains 63 points in its checklist. The algorithm can be run over a word list or arbitrary text in ordinary spelling; it first phonetically transcribes the text, and then tags it with identified difficulty points to produce output shown in Figure 6. All type of phonolapsological statistics and analyses can be initiated at this point. PDI has been used to study, among others, the phonolapsological profile of dictionary definitions (Sobkowiak 2006a) and graded readers (Sobkowiak and Ferlacka 2011).

The PDI algorithm has been run on the mini-corpus of coursebook text collected in ways described earlier. Some of the global PDI statistics gleaned from this analysis appear in Table 1. The 'then' column shows data for the four older textbooks, the 'now' column - for the three new ones. With this size sample no statistically significant effects can be obtained, but the observed differences are certainly interesting and promising for potential further research. 


\begin{tabular}{|l|r|r|}
\hline & then & now \\
\hline \# records & 37 & 40 \\
\# words & 135 & 209 \\
average record length (in words) & 3.65 & 5.22 \\
average PDI value per record & 5.62 & 7.78 \\
average PDI value per word & 1.54 & 1.48 \\
\# 'easy' words (with PDI=0) & 10 & 59 \\
average 'easy' words per record & 0.27 & 1.48 \\
\hline
\end{tabular}

Table 1. Some phonolexical statistics: 'then' versus 'now'

It will be seen that, while the number of records (sentences) is roughly equivalent for both sub-samples, the number of words differs: apparently the sentences are now longer than they used to be. This can, of course be observed if Figure 5 is compared with the previous ones: gone are the strangely concise? These are walls entries in favour of more communicatively felicitous, and longer, sentences. With longer sentences the overall PDI value per sentence must grow as well, of course; it goes from 5.6 to 7.8 between 'then' and 'now'. In plain language this means that there were almost six points of pronouncing difficulty in one sentence in the beginning sections of the 'old' textbooks, but there are almost eight such points in the equivalent sample of contemporary textbooks. In all of my past work with PDI, however, this statistic has been weighted by the number of words in a record, to avoid the counterintuitive claim that a longer sentence is ipso facto phonetically harder than a shorter one. If word-weighting is applied to the data at hand, the average PDI value figures for 'then' versus 'now' are not very different, as can be seen in the table ${ }^{2}$. Interestingly, the value seems to have gone down a bit, the effect which is more dramatically observed in the number of 'easy' words per record across the two sub-corpora: this has grown more than five times between then and now. Should this turn out in further research to be a robust effect, it could be evidence that textbook writers do tend to make their resources more phonetically user-friendly than used to be the case half a century ago. This is not to claim that phonolapsological control is wielded directly; rather that some other editorial decisions and choices indirectly affect the phonetic profile of the text. Incidentally, this is also the phenomenon observed in the PDI analysis of pedagogical dictionary definitions and graded readers.

In a larger study of textbook phonolapsology this would be an entry point to a more thorough treatment of the collected corpus text. Space restrictions do not allow this here. But a few more examples can be provided of how PDI can be used not only to analyze textbooks for the benefit of writers and editors, but also to assist teachers and learners in their tasks of evaluation and selection, mentioned at the beginning of this paper. Because the PDI algorithm not only computes the overall PDI value of a word or sentence, but also tags each word or sentence with the specific phonetic difficulty points it contains, as exemplified in Figure 6, it is possible to select wanted material from text with a fair

\footnotetext{
${ }^{2}$ This value is notably lower, by the way, than the mean word-weighted PDI value counted over the corpora of controlled-vocabulary dictionary definitions (Sobkowiak 2006a) or of simplified graded readers (Sobkowiak and Ferlacka 2011), where mean PDI=1.79.
} 
degree of precision. Thus, not only can one obtain sentences with the highest/lowest PDI value in the sample: I work with many other teachers men and women (PDI=16), Peter and John are talking to their wives ( $\mathrm{PDI}=21)$, I like music (PDI=0), My name is Max (PDI=0.5, word-weighted), but one can also request sentences with a high/low incidence of a given PDI code or code cluster (see Sobkowiak 2006b for so-called PDI codegrams). If word-final (de)voicing is under study or practice, for example, sentences with many instances of $\mathrm{PDI}(\mathrm{Z})$ can be located: This is his dog, I teach many students girls and boys, I work with many other teachers men and women (all with 3 occurrences). By contrast, if no word-final voiced obstruents are wished for, it is easy to use PDI to come up with: I teach in a school in Coventry, They are all very intelligent, I like music.

Similarly precise queries can be easily formulated for all of the 63 PDI codes. Likewise, it is possible to combine queries for specific PDI codes with those for PDI values, e.g.: give me those sentences which are generally phonetically easy, i.e. low PDI, but with a high proportion of words containing a given phonetic difficulty. All of the other existing variables, such as sentence word-length, word spelling, or textual frequency, could be similarly combined into such queries.

\section{Conclusions}

The underlying theme of this preliminary study is the notion that because textbooks are of such fundamental pedagogical importance in the foreign language classroom, the underlying phonetic and phonolapsological profile of the texts used must have a powerful effect on acquisition of the target language pronunciation. If this hypothesis sounds prima facie somewhat less plausible than if it applied to the grammatical or lexical structure of beginners' coursebooks it might be due to the current state of the art when it comes to EFL pronunciation teaching and research, i.e. the general neglect mentioned at the beginning of this paper. While grammar and vocabulary are under strict editorial control in beginners' textbooks, and hence expected to bring targeted consequences in terms of learning, acquisition, skill and proficiency, pronunciation is seldom, if at all, treated in this way, at least outside of dedicated phonetic coursebooks, which are not normally used with beginners anyway.

If this inference generally makes sense, then, a thorough phonetic study of EFL textbooks becomes a necessity. This can be done in a number of ways, of course, and with a variety of tools. What I have demonstrated in this paper is just one such tool, namely PDI, and one methodology, namely a contrastive chronological look at textbooks 'then' versus 'now'. Quite apart from the phonetic and phonolapsological study of textbooks, it would also be extremely interesting to compare the actual effect of textbooks, one or two (human) generations apart, on the EFL achievement, phonetic and otherwise, of learners belonging to those generations. This, needless to say, would be a project of enormous proportions and complexity. 


\section{References}

Alexander, Louis George [pseud.]. 1973. First things first: an integrated course for beginners. Warszawa: PWN. [Reprint of the first English edition, 1967, Harlow: Longman]

Baran-Łucarz, Małgorzata. 2006. Prosto w oczy - fonetyka jako "Michałek" na studiach filologicznych?. In Dydaktyka fonetyki języka obcego w Polsce, eds. Włodzimierz Sobkowiak and Ewa Waniek-Klimczak, 7-17. Konin: Wydawnictwo Państwowej Wyższej Szkoły Zawodowej.

Birkenmajer, Maria and Elżbieta Mańko. 2004. Korepetycje domowe. Jezyk angielski (nowa edycja). Warszawa: Langenscheidt Polska.

Candlin, Edwin Frank. 1963. Present day English for foreign students. Warszawa: Państwowe Wydawnictwo Wiedza Powszechna. [Reprint of the first English edition, 1963, London: Hodder and Stoughton]

Cunningsworth, Alan. 1995. Choosing your coursebook. Oxford. Heinemann.

Dostalova, Iva, Sarka Zelenkova and James Branam. 2011. Angielski dla samouków. Ożarów Mazowiecki: Firma Księgarska Olesiejuk. [Reprint of the Czech edition, 2003, Praha: Fragment]

İnal, Bülent. 2006. Coursebook selection process and some of the most important criteria to be taken into consideration in foreign language teaching. Journal of Arts and Sciences 5: 19-29.

MacCallum and Thomas Watson. 1946. Nauka angielskiego; szybko, tatwo i przyjemnie. Celle-Unterlüss: Wydawnictwo Antoniego Markiewicza. [Reprint of the English edition, 1937, Nauka angielskiego. English for Poles. An easy and quick method; London: Orbis]

Nowak, Agata. 2011. Angielski nie gryzie! Warszawa: Wydawnictwo Edgard.

Rivers, Wilga M. 1981. Teaching foreign-language skills. Chicago University Press: Chicago.

Smólska, Janina and Jan Rusiecki. 1965. [1st ed. 1963]. English for everyone. Warszawa: Państwowe Zakłady Wydawnictw Szkolnych.

Sobkowiak, Włodzimierz. 1997. Radically simplified phonetic transcription for Polglish speakers. In Language history and linguistic modelling. Festschrift for Jacek Fisiak on his 60th birthday, eds. Raymond Hickey and Stanisław Puppel, 1801-1830. Berlin: Mouton.

Sobkowiak, Włodzimierz. 1999. Pronunciation in EFL Machine-Readable Dictionaries. Poznań: Motivex.

Sobkowiak, Włodzimierz. 2004. Phonetic Difficulty Index. In Dydaktyka fonetyki języka obcego. Zeszyt Naukowy Instytutu Neofilologii Państwowej Wyższej Szkoty Zawodowej $w$ Koninie $n r$ 3., eds. Włodzimierz Sobkowiak and Ewa WaniekKlimczak, 102-107. Konin: Wydawnictwo Państwowej Wyższej Szkoły Zawodowej.

Sobkowiak, Włodzimierz. 2006a. Phonetics of EFL dictionary definitions. Poznań: Wydawnictwo Poznańskie. 
Sobkowiak, Włodzimierz. 2006b. PDI revisited: lexical cooccurrence of phonetic difficulty codes. In Dydaktyka fonetyki języka obcego. Neofilologia VIII. Zeszyty naukowe Państwowej Wyższej Szkoły Zawodowej w Płocku, eds. Włodzimierz Sobkowiak and Ewa Waniek-Klimczak, 225-238. Płock: Wydawnictwo Państwowej Wyższej Szkoły Zawodowej.

Sobkowiak, Włodzimierz and Wiesława Ferlacka. 2011. PDI as a tool of phonetic enhancements to graded e-readers. In The acquisition of L2 phonology, eds. Janusz Arabski and Adam Wojtaszek, 138-158. Bristol: Multilingual Matters.

Szpyra-Kozłowska, Jolanta et al. 2003. Komponent fonetyczny w podręcznikach przygotowujących do egzaminów Cambridge (FCE, CAE, CPE). In Zeszyt Naukowy Instytutu Neofilologii Państwowej Wyższej Szkoły Zawodowej w Koninie nr 2, eds. Włodzimierz Sobkowiak and Ewa Waniek-Klimczak, 137-144. Konin: Wydawnictwo Państwowej Wyższej Szkoły Zawodowej.

Szymańska-Czaplak, Elżbieta. 2006. Nauczanie fonetyki w szkole na poziomie elementarnym - analiza wybranych podręczników do nauki języka angielskiego. In Dydaktyka fonetyki języka obcego w Polsce, eds. Włodzimierz Sobkowiak and Ewa Waniek-Klimczak, 231-238. Konin: Wydawnictwo Państwowej Wyższej Szkoły Zawodowej.

Wrembel, Magdalena. 2004. Beyond 'listen and repeat' - an overview of English pronunciation teaching materials. In Dydaktyka fonetyki języka obcego. Zeszyt Naukowy Instytutu Neofilologii Państwowej Wyższej Szkoły Zawodowej w Koninie nr 3., eds. Włodzimierz Sobkowiak and Ewa Waniek-Klimczak, 171-179. Konin: Wydawnictwo Państwowej Wyższej Szkoły Zawodowej. 